UDC 811.111.248'19

DOI https://doi.org/10.26661/2414-1135-2020-80-2-2

\title{
INTONATION PECULIARITIES OF ENGLISH JUDICIAL DISCOURSE
}

\author{
Matiienko-Silnytska A. V. \\ Lecturer at the Department of Foreign Languages № 1 \\ National University "Odesa Law Academy" \\ Akademichna str., 2, Odesa, Ukraine \\ orcid.org/0000-0001-5097-0302 \\ matienkoanna07@gmail.com
}

Key words: oral English court speeches, auditory analysis, compositional parts, pitch, loudness, tempo, persuasion.
The article is devoted to the description of the results of the auditory analysis of the texts belonging to a judicial discourse. The immediate aim of the article is to identify the peculiarities of the intonation organization of the oral English court speeches. The object of the study is judicial discourse as a special type of institutional discourse of persuasive type. The subject of the study is the peculiarities of the intonation organization of oral court speeches, proclaimed during court hearings by a defence counsel and a prosecutor. To achieve the aim, a phonetic study of the perceived prosodic characteristics of speech realizations of court speech was carried out, in the process of which the subjective method of scientific observation was used, which contains auditive and auditory analysis of the selected objects as well as determining the phonological status of the studied units; quantitative analysis made it possible to interpret the data obtained empirically during the auditory analysis. The conducted auditive and auditory analysis made it possible to draw certain conclusions concerning the intonation organization common for the studied oral texts of judicial discourse. The identification by the auditors of parts of the court speeches of the prosecutor and the defence counsel proved the validity of their division into the compositional parts and made it possible to conclude that there are certain linguistic factors that allow to identify parts of the text with the high degree of probability. The leading intonation parameter for achieving or strengthening the convincing effect of the speeches is considered the tempo. The melodic component of intonation, namely the melodic contour, has also proved to be a powerful intonation means of influencing and achieving a persuasive effect, while loudness is not considered to be an important intonation parameter involved in persuasion. The conducted study has identified the role of the components of intonation (pitch, loudness and tempo) in the implementation of the function of persuasion of the institutional discourse. 


\title{
ІНТОНАЦЙНІ ОСОБЛИВОСТІ АНГЛОМОВНОГО СУДОВОГО ДИСКУРСУ
}

\author{
Матіснко-Сільницька А. В. \\ викладач кафедри іноземних мов № 1 \\ Національний університет «Одеська юридична академія» \\ вул. Академічна, 2, Одеса, Україна \\ orcid.org/0000-0001-5097-0302 \\ matienkoanna07@gmail.com
}

Ключові слова: усні англійські судові промови, слуховий аналіз, композиційні частини, висота тону, гучність, темп, переконання.
Статтю присвячено опису результатів аудиторського аналізу текстів, що належать до судового дискурсу. Безпосередньою метою статті $\epsilon$ виявлення особливостей інтонаційної організації усних англійських судових промов. Об'єктом дослідження є судовий дискурс як особливий тип інституціонального дискурсу переконуючого типу. Предметом дослідження є особливості інтонаційної організації усних судових промов, проголошених під час судових засідань захисником та прокурором. Для досягнення мети було проведено фонетичне вивчення сприйманих просодичних характеристик мовленнєвих реалізацій судової мови, в процесі якого використано суб'єктивний метод наукового спостереження, що містить аудитивний та аудиторський аналіз обраних об'єктів, визначення фонологічного статусу досліджуваних одиниць; кількісний аналіз дозволив інтерпретувати дані, отримані емпірично під час слухового аналізу. Проведений аудиторський та слуховий аналіз дозволив зробити певні висновки щодо інтонаційної організації, загальної для усних текстів судового дискурсу, що вивчалися. Виявлення аудиторами частин судових промов прокурора та захисника засвідчило обгрунтованість їх розподілу на композиційні частини та дало змогу зробити висновок про наявність певних лінгвістичних факторів, що дозволяють ототожнювати частини тексту 3 високим ступенем ймовірності. Провідним інтонаційним параметром для досягнення або посилення переконуючого ефекту промов вважається темп. Мелодійний компонент інтонації, а саме мелодійний контур, також виявився потужним інтонаційним засобом впливу та досягнення переконуючого ефекту, тоді як гучність не вважається важливим інтонаційним параметром, який бере участь у переконанні. Проведене дослідження визначило роль компонентів інтонації (висота, гучність та темп) у реалізації функції переконання інституційного дискурсу.
The influential effect of any oral institutional public speech is achieved by using not only lingual and compositional means, but also prosodic means of influence. That is why the study of intonation features of texts of oral English judicial speeches at the level of perception is relevant and promising to identify the role of components of intonation (pitch, loudness and tempo) in the implementation of the function of persuasion of the institutional discourse. Since judicial speeches are one of the most influential and most expressively coloured implementations of institutional discourses, it can be considered appropriate to study the prosodic characteristics of the texts of attorney's and prosecutor's speech within judicial discourses.
The basis for the attribution of court speech to institutional discourses is the definition of T.A. van Dijk, who states that "the institutional discourse is a stable system of status-role relations that has developed in the communicative space of a social institution, in which the power functions of symbolic coercion in the form of normative prescription and legitimation of certain ways of worldview, mentality, value orientations vectors and patterns of behaviour" [4, p. 16].

According to V. Karasyk, the constitutive features of the institutionality of a discourse include the role characteristics of agents and clients of the institutes, a typical chronotope (time and place characteristics), symbolic actions, stencil genres and language clichés. Typological features of the institutional discourse are 
the type of public institution, which in the collective lingual consciousness is marked by a special name, associated with certain functions of people, structures built to perform such functions, social rituals and behavioural stereotypes, mythologies, and texts produced in this social formation [3, p. 7].

Theoretical and applied problems of judicial linguistics are presented in the scientific works of Ukrainian and foreign scientists (T. Brostoff, I. Fairclough, M. Holev, T. Hubaieva, J.Thompson, I Voropaiev and others). The works of S. Goźdź-Roszkowski, I. Hlovatsky, L. Pavlova,L. Vedenska, and others are devoted to the rhetorical peculiarities of judicial discourse. The analysis of the peculiarities of judicial discourse from the point of view of communicative linguistics was carried out in the works of T. Dubrovska, O. Kobzeva, V. Kukovska, N. Ovchinnikova, L. Ponomareva, and others. Judicial discourse in most works is understood as a kind of legal discourse, which is a verbal-symbolic reflection of the communication process during the trial and is considered in view of the characteristics and intentions of the participants $[2$, p. 10]. The intentions of the participants are based on the idea of justice. The theory of justice "that can serve as the basis of practical reasoning must include ways of judging how to reduce injustice and advance justice, rather than aiming only at the characterization of perfectly just societies - an exercise that is such a dominant feature of many theories of justice" $[5$, p. 32]. O. Dotsenko notes that judicial discourse is "clearly regulated by extra linguistic factors: procedural legislation, the level of legal and communication training and functions of participants, a high degree of emotional tension determined by the interest of court participants in criminal, civil, administrative cases, etc." [1, p. 270]. This definition emphasizes an important feature of the discourse under study - regulation and ritual, which allows to refer judicial discourse to a purely institutional: participants in judicial discourse perform clearly defined social roles, which are characterized by appropriate models of communicative behaviour, subject to the intentions of speakers. Taking into consideration the high degree of argumentativeness and influence, judicial discourse should be classified as a special type of institutional discourse of a persuasive type.

The aim of this article is to identify the peculiarities of the intonation organization of the oral English court speeches. The object of the study is judicial discourse as a special type of institutional discourse of persuasive type. The subject of the study is the peculiarities of the intonation organization of oral court speeches, proclaimed during court hearings by a defence counsel and a prosecutor. The study is based on video recordings of 12 English speeches by the defence counsel and 12 speeches by the prosecutor from the British court hearings "In the courtroom" (the transcript of which is equal to 53 pages of printed text in A4 format, 14 Times New Roman font).

To achieve this goal, a phonetic study of the perceived prosodic characteristics of speech realizations of court speech was carried out, in the process of which the method of scientific observation (subjective) was used, which contains auditive and auditory analysis of the selected objects as well as determining the phonological status of the studied units; quantitative analysis made it possible to interpret the data obtained empirically during the auditory analysis.

The study of the compositional structure of the text of oral English court speeches suggests the existence of a common structure of the defence counsel's speech and the prosecutor's speech. In this article we do not take into account the connotation (positive or negative) of the circumstances of the case and the conclusions. Obviously, the speeches of the defence counsel and the accuser are polar in assessment, but identical in structure. Judicial practice has developed the following structure of judicial speech: introductory part; the plot of the case (statement of the facts of the crime); analysis and evaluation of the evidence collected in the case (analysis of evidence); substantiation of the qualification of the crime; concluding part of the speech.

The perceptual analysis performed in the work was used to highlight the characteristic functional features of speech factors, as during the perceptual analysis the intonation characteristics of speech signals are revealed, which allow the listener to interpret adequately the speaker's speech messages.

The auditory analysis, which was preceded by the author's previous perceptual analysis, consisted of two stages. At the first stage of the auditory analysis, the auditors were asked to determine to which compositional part of the speech the proposed speech realizations belong. During the same stage, the auditors determined the degree of participation of certain prosodic parameters (melodic contour, phrasal stress, loudness, tempo, rhythm, pausation) in the persuasion function implementation in different parts of the text.

The analysis of the auditors' answers on determining whether the segments of speech they listened to belonged to one or another part of the speech showed with almost one hundred per cent probability that the auditors recognized the final part (on average 99.1\% in the prosecutor's speech and $98.9 \%$ in the defence counsel's speech). $98.8 \%$ in the prosecutor's speech and $98.7 \%$ in the defence counsel s speech). A slightly lower percentage of correct answers was registered during the identification of the main part of the court speech, primarily in the part of analysis of evidence (on average $-92 \%$ of correct answers). In general, the auditory analysis at this stage has proved the relevancy of the speeches division into the above mentioned semantic parts, and has allowed concluding 
that there are certain linguistic and extra lingual factors that allow to identify parts of the speeches with a high degree of probability.

Determining by the auditors the degree of intonation participation in the implementation of the persuasive function in different parts of the text allows us to state that all these prosodic parameters to some extent participate in creating a persuasive effect. First of all, it concerns the temporal component of intonation - tempo, rhythm, pauses. According to the auditors, loudness is not considered to be the leading intonation parameter involved in persuasion. This opinion can be explained by the fact that the studied oral speeches belong to public speeches, aimed at a large audience, which implies an increased volume and intensity of pronunciation. The melodic component of intonation, namely the melodic contour, according to the auditors' answers, is a powerful intonation means of influencing and achieving a convincing effect.

At the second stage of the auditory analysis, the auditors were to note the characteristic intonation features of the studied texts: tempo, pitch, loudness.

The results of the perception of the rate of speech in the excerpts of the speeches listened to by the auditors are shown in Table 1.

The data show that, on average, in the text, the auditors perceive mostly normal and slow rate of utterance of statements in both types of speeches. Only in the main part of the plot the auditors recorded relatively high percentage of accelerated rate of utterance $(17.9 \%$ in the speech of the prosecutor and $20.8 \%$ in the speech of the defence counsel). The rest of the parts in both implementations of the judicial discourse are not characterized by the use of the accelerated rate, especially the concluding part. The highest percentage of slow rate usage was recorded in the concluding part of the prosecutor's speech $(58.2 \%)$ and the defence counsel's speech $(62.1 \%)$, which gives grounds to consider the use of slow rate in the most important and influential parts of the text to be a characteristic feature of the studied discourse.

The next most informative component of intonation, according to the auditors' answers, was the melodic contour, which involves changing of the pitch of the voice. The results of the analysis of the auditors' responses to the identification of the pitch level of utterances are presented in Table 2.

According to the data presented in the table, the auditors generally registered the predominant use of medium pitch level by the speakers, which is the norm for English intonation. However, the auditors' responses made it possible to identify a common tendency in the usage of high and low pitch levels in different parts of the text. Thus, the final part of the court speech is characterized by a significant deviation of speakers from the normal pitch level towards both high $(27.1 \%$ and $28.7 \%$, respectively) and low (33.1\% and $28.6 \%$, respectively) pitch level. This contrasting melodic organization of the semantically important part of the court speech gives more emotional tension to the utterance and, as a consequence, leads to a persuasive effect. In terms of analysis and substantiation, the speakers, despite the predominantly normal pitch level, often (on average in $20 \%$ of cases) also use a low pitch level, which gives weight to the arguments presented.

As noted above, loudness is not considered by the auditors to be a leading intonation parameter involved in persuasion. Nevertheless, the auditors' assessment of the volume level of the parts of the speeches they listened to allows us to speak about the existence of a certain regularity. It is that the low level of loudness in the text is generally registered by the auditors only in $6.2 \%$ and $5.5 \%$ of cases, respectively. At the same time, the level marked as "quiet" is not registered in the introductory and concluding parts of both implementations of judicial discourse in general. The normal level of loudness is mostly characteristic of the part of the plot of the court speech, as evidenced by the relatively high percentage of phrases, which the auditors marked

Perceived characteristics of the tempo in different parts of the court speech (\%)

\begin{tabular}{|c|c|c|c|c|}
\hline \multicolumn{2}{|l|}{ Part of the speech } & Quick & Normal & Slow \\
\hline \multirow{2}{*}{ Introductory } & prosecutor's speech & 2.1 & 48.2 & 47.3 \\
\hline & defence counsel 's speech & 3.4 & 45.8 & 49.2 \\
\hline \multirow{2}{*}{ Plot } & prosecutor's speech & 17.9 & 55.1 & 29.5 \\
\hline & defence counsel 's speech & 20.8 & 58.9 & 24.3 \\
\hline \multirow{2}{*}{ Analysis and substantiation } & prosecutor's speech & 7.7 & 56.2 & 35.1 \\
\hline & defence counsel 's speech & 5.9 & 42.7 & 48.4 \\
\hline \multirow{2}{*}{ concluding } & prosecutor's speech & 1.3 & 42.7 & 58.2 \\
\hline & defence counsel 's speech & 2.4 & 35.2 & 62.1 \\
\hline \multirow{2}{*}{ average } & rosecutor's speech & 7.25 & 50.6 & 41.9 \\
\hline & ence counsel 's speech & 8.1 & 45.7 & 47.5 \\
\hline
\end{tabular}


Table 2

Perceived characteristics of the pitch level of different parts of the court speech (\%)

\begin{tabular}{|c|c|c|c|c|}
\hline Part of the & $\begin{array}{l}\text { Pitch } \\
\text { Level }\end{array}$ & High & Medium & Low \\
\hline \multirow{2}{*}{ Introductory } & prosecutor's speech & 11.8 & 69.4 & 11.8 \\
\hline & defence counsel's speech & 15.2 & 67.4 & 7.3 \\
\hline \multirow{2}{*}{ Plot } & prosecutor's speech & 20.4 & 65.3 & 14.3 \\
\hline & defence counsel 's speech & 22.1 & 63.1 & 14.8 \\
\hline \multirow{2}{*}{ Analysis and substantiation } & prosecutor's speech & 12.2 & 62.0 & 15.8 \\
\hline & defence counsel's speech & 13.6 & 64.9 & 21.5 \\
\hline \multirow{2}{*}{ concluding } & prosecutor's speech & 27.1 & 39.2 & 29.7 \\
\hline & defence counsel 's speech & 28.7 & 38.2 & 33.1 \\
\hline \multirow{2}{*}{ average } & prosecutor's speech & 16.9 & 58.9 & 28.6 \\
\hline & defence counsel 's speech & 19.9 & 58.3 & 21.8 \\
\hline
\end{tabular}

as phrases with a normal level of loudness $(41.1 \%$ and $42.9 \%$, respectively). According to the auditors, approximately $80 \%$ of the phrases from the introduction and $75 \%$ of the phrases of the final part can be considered loud. In general, based on the analysis of the loudness level of different parts of the speech of the prosecutor and defence counsel at the perceptual level, we can state the predominance of the increased loudness in all parts of the studied speeches, especially in the introductory and concluding.

Thus, on the basis of the conducted auditive and auditory analysis it is possible to draw certain conclusions concerning the intonation organization common for the studied oral texts of judicial discourse. The identification by the auditors of parts of the court speeches of the prosecutor and the defence counsel proved the validity of their division into the compositional parts and made it possible to conclude that there are certain linguistic factors that allow to identify parts of the text with the high degree of probability. The leading intonation parameter for achieving or strengthening the convincing effect of the speeches is considered the tempo. The melodic component of intonation, namely the melodic contour, has also proved to be a powerful intonation means of influencing and achieving a persuasive effect, while loudness is not considered to be an important intonation parameter involved in persuasion. The prospect of further research is seen in the conduct of a comprehensive instrumental phonetic analysis, which will provide verification of the data obtained on the perceptive prosodic organization of persuasive utterances in the judicial discourse.

\section{BIBLIOGRAPHY}

1. Доценко О.Л. Жанрова специфіка українського судового дискурсу. Мовні $і$ конщеп- туальні картини світу. 2008. Вип. 24. Ч. 1. C. $269-280$.

2. Дубровская Т.В. Судебный дискурс: речевое поведение судьи : автореф. дис. ... д. філол. наук : 10.02.01. Саратов, 2010. 39 с.

3. Карасик В.И. О типах дискурса. Языковая личность: институциональный и персональный дискурс: сб. науч. тр. Волгоград : Перемена, 2000. С. 5-20.

4. Dijk T. A.van. Introduction: Discourse Analysis as a New Cross-Discipline. Handbook of Discourse Analysis. Vol. 1. Academic Press, 1985. 18 p.

5. Sen A. The Idea of Justice. The Belknap Press of Harvard University Press, Cambridge, Massachusetts, 2009. 467 p.

\section{REFERENCES}

1. Dotsenko O. L. (2008) The genre specifics of Ukrainian trial discourse [Zhanrova spetsyfika ukrainskogo sudovogo dyskursu]. Linguistic and conceptional views of the world [Movni $\mathrm{i}$ kontseptualni kartyny svitu]. Issue 24. Part. 1. P. 269-280.

2. Dubrovskaya T. V. (2010) Trial discourse: verbal behavior of a judge [Sudebnyiy diskurs: rechevoe povedenie sudii ]. Saratov, $39 \mathrm{p}$.

3. Karasik V. I. (2000) On discourses' types [O tipah diskursa]. Linguistic individual: institutional and personal discourse [Yazykovaya lichnost: institutsionalnyiy i personalnyiy dyskurs]. Volgograd: Peremena, P. 5-20.

4. Dijk T. A.van. (1985) Introduction: Discourse Analysis as a New Cross-Discipline. Handbook of Discourse Analysis. Vol. 1. Academic Press, 18 p.

5. Sen A. The Idea of Justice. (2009) The Belknap Press of Harvard University Press, Cambridge, Massachusetts, $467 \mathrm{p}$. 